\title{
Effects of Socio-economic, Demographic and Internet Exposure Factors on School Performance among Selected Students of Nilkhet High School.
}

\author{
Abdullah Ibn Mafiz ${ }^{1}$ Ila Ismail ${ }^{2}$ and M A H Bhuyan ${ }^{2}$ \\ Mawlana Bhashani Science and Technology University, Tangail ${ }^{1}$ \\ Institute of Nutrition and Food Science, University of Dhaka ${ }^{2}$
}

\begin{abstract}
:
A cross sectional study was carried out to investigate the effects of socio-economic, demographic and internet exposure factors on school performance among 10 grade students of Nilkhet High School. All of the eighty seven students were selected for this study. In this study school performance was measured by class roll number. The lower the class roll number the better the school performance. During Chisquare test grade $(\mathrm{A}+, \mathrm{A}, \mathrm{A}-, \mathrm{B}, \mathrm{C}, \mathrm{D})$ achieved in the class 9 final examination was taken as dependent variable. An upper grade indicates better school performance than lower grade. Class roll number were highly negatively correlated with the factors-actual income of the family, actual monthly tuition cost, number of rooms in the house, number of earning persons in the family, and this correlation was significant $(p<0.01)$ at $1 \%$ level of significance. Chi-square test was used to check for association between the category of these factors and the school performance measured by grade. Chi-square test also found highly significant. In Chi-square test some of the other factors namely highest education of mothers $(\mathrm{p}<0.05)$, highest education of fathers $(p<0.05)$, occupation of fathers $(p<0.01)$, and occupation of mothers $(\mathrm{p}<0.05)$ were significant. Maximum $80.7 \%$ change in school performance was found when we studied the aggregate effects of fourteen factors. The school performance measured by grade of the students was significantly related with the work on internet and number of friends in Facebook because the Chi-square test shows the $\mathrm{P}$-value $<0.01$. Maximum $43.5 \%$ changes occurred in school performance when number of friends in Facebook was significant at $1 \%$ level of significance and both work on internet and Facebook account were significant at $10 \%$ level of significance.
\end{abstract}

Key Words: Socio-economic, Demographic, Internet Exposure and School Performance.

Bangladesh Journal of Nutrition. Vol. 24-25 December, 2011-2012. Institute of Nutrition and Food Science, University of Dhaka, Dhaka-1000, Bangladesh.

* Author for Correspondence 


\section{Introduction:}

Academic performance is the ability to study and remember facts and being able to communicate the acquired knowledge verbally or down on paper. A person's education is closely linked to their life chances, income, and well being ${ }^{1}$. The school performance of children is also heavily influenced by socio-economic and demographic factors. Sex has an influence on school performance, although it's a matter of dispute. The environment at home is a primary socialization agent and influences a child's interest in school and aspirations for the future. The socioeconomic status (SES) of a child is most commonly determined by combining parent's educational level, occupational status, and income level ${ }^{2}$. It is believed that low SES negatively affects academic achievement because low SES prevents access to vital resources and creates additional stress at home ${ }^{3,4,2}$. Research shows that supportive and attentive parenting practices positively affect academic achievement $^{3}$. Maternal characteristics are another key factor that affect academic achievement ${ }^{5,3,4}$. Mothers who are more educated and have higher self-esteem have children who receive higher test scores ${ }^{5,3}$. Smaller family size has been linked with higher academic achievement ${ }^{3,4}$.

Facility of internet use, time spent on internet and activities on internet plays a great role in the performance of school children. Research has examined the general impact of technology on academic achievement and development of children and teens. Positive and negative effects of technology achievement have been documented. Espinosa, Laffey, Whittaker, and Sheng (2006) investigated the role of technology in early childhood development using data from the Early Childhood Longitudinal Study. The results indicated that access contributed to the learning potential of the students.

\section{Materials and Methods:}

\subsection{Type of Study:}

A cross sectional sample survey was carried out among 10 grade students of Nilkhet High School in Dhaka city.

\subsection{Basis for Selection of Study Place:}

Well communicated.

Assurance from the school authority for full co-operation.

\subsection{Study Population and Sample Size :}

The study population was the 10 grade students of Nilkhet High School. There were 87 students in grade 10 . Among them 14 are assigned to science group, 64 assigned to commerce group and 9 are assigned to arts group. As because there were only 87 students, that's why all of them were included in this study. So sample size (N) was also 87. 


\subsection{Research Instruments:}

Development of the questionnaire: A questionnaire was developed containing both close and open ended questions to obtain relevant information on internet exposure, socio-economic and demographic condition.

\subsection{Data Collection:}

Questionnaire was asked passively and cautiously not to influence the respondents.

Collection of socio-economic, demographic and internet exposure information:

The part of the questionnaire that was designed to obtain socio-economic information was collected by interviewing the respondents. All of the respondents were interviewed about demographic and internet exposure information. All of the information's were recorded in the respective places of the questionnaire.

\subsection{Data Verification:}

Questionnaires were checked each day after interviewing and again these were carefully checked after completion of all data collection and coded before entering into the computer. The data was edited if there was any discrepancy (doubt entry, wrong entry etc).

\subsection{Statistical Analysis:}

All of the statistical analysis and all other data processing were done by using SPSS 16.0 windows program. For tabular, charts and graphical representation Microsoft Word and Microsoft Excel were used.

Descriptive statistics: Descriptive statistics quantitatively describe the main features of a collection of data.

Frequency distribution: A frequency distribution is an arrangement of the values that one or more variables take in a sample. Each entry in the table contains the frequency or count of the occurrences of values within a particular group or interval, and in this way, the table summarizes the distribution of values in the sample.

Bivariate analysis: Bivariate analysis is one of the simplest forms of the quantitative (statistical) analysis. It involves the analysis of two variables (often denoted as $\mathrm{X}, \mathrm{Y}$ ), for the purpose of determining the empirical relationship between them. In order to see if the variables are related to one another, it is common to measure how those two variables simultaneously change together.

Multivariate analysis: Multivariate analysis is based on the statistical principle of multivariate statistics, which involves observation and analysis of more than one statistical variable at a time. In design and analysis, the technique is used to perform 
trade studies across multiple dimensions while taking into account the effects of all variables on the responses of interest.

General expression of linear model is given in Equation 1

$$
\mathrm{Y}=\beta_{0}+\beta_{1} \mathrm{X}_{1}+\beta_{2} \mathrm{X}_{2}+
$$
$+\beta_{\mathrm{i}} \mathrm{X}_{\mathrm{i}}+\mathrm{C}$

(1)

Here,

$\mathrm{Y}=$ Dependent variable

$\mathrm{X}_{\mathrm{i}}=\mathrm{i}^{\text {th }}$ Factor

\section{Results:}

\subsection{Effects of Socio-Economic and Demographic Factors on School Performance}

Descriptive statistics:

Table 1: Descriptive statistics of Socio-economic and demographic factors of school performance $(n=87)$.

\begin{tabular}{|c|c|c|c|c|}
\hline Variable & (Mean \pm S.E.) & S.D. & Minimum & Maximum \\
\hline Age & $15.15 \pm 0.07$ & 0.64 & 14.00 & 16.00 \\
\hline Total siblings & $2.69 \pm 0.14$ & 1.21 & 0.00 & 5.00 \\
\hline $\begin{array}{c}\text { Actual income of the } \\
\text { family }\end{array}$ & $28379 \pm 714.06$ & 6660.35 & 18000.00 & 43000.00 \\
\hline $\begin{array}{c}\text { Actual monthly tuition } \\
\text { cost }\end{array}$ & $2908 \pm 109.83$ & 1024.49 & 1500.00 & 5000.00 \\
\hline $\begin{array}{c}\text { No of rooms in the } \\
\text { house }\end{array}$ & $3.08 \pm 0.09$ & 0.73 & 2.00 & 5.00 \\
\hline No of earning person & $1.78 \pm 0.05$ & 0.49 & 1.00 & 3.00 \\
\hline
\end{tabular}

Table 1 depicts the mean, standard deviation, minimum and maximum value for socio-economic and demographic factors that affects school performance. The age of the students ranges from 14 to 16 years with a mean value of 15.15 years. Maximum value for sibling was 5. The mean for actual income of the family was 28379 TK, where maximum value was 43000 TK and minimum value was 18000 TK. There were maximum 5 rooms in their house. The mean for number of earning person in the family was 1.78 with a minimum value of 1 and maximum value of 3 . 
Frequency distribution:

Table 2: Frequency distribution of socio-economic and demographic factors of school performance $(n=87)$.

\begin{tabular}{|c|c|c|c|}
\hline Variable & Category & Frequency & Percent (\%) \\
\hline \multirow[t]{2}{*}{ Religion } & Muslim & 77 & 88.5 \\
\hline & Hindu & 10 & 11.5 \\
\hline \multirow{3}{*}{$\begin{array}{l}\text { Highest education } \\
\text { of mother }\end{array}$} & Class 1-10 \& SSC & 74 & 85.1 \\
\hline & Class 11-12 \& HSC & 12 & 13.8 \\
\hline & Graduate & 1 & 1.1 \\
\hline \multirow{4}{*}{$\begin{array}{l}\text { Highest education } \\
\text { of father }\end{array}$} & Class 1-10 \& SSC & 2 & 2.3 \\
\hline & Class 11-12 \& HSC & 54 & 62.1 \\
\hline & Graduate & 29 & 33.3 \\
\hline & Master degree \& above & 2 & 2.3 \\
\hline \multirow{3}{*}{$\begin{array}{l}\text { Occupation of } \\
\text { mother }\end{array}$} & Housewife & 76 & 87.4 \\
\hline & Govt. job & 7 & 8.0 \\
\hline & Private job & 4 & 4.6 \\
\hline \multirow[t]{2}{*}{ Type of house } & Building & 65 & 74.7 \\
\hline & Building with roof of tin & 22 & 25.3 \\
\hline \multirow{4}{*}{$\begin{array}{l}\text { Monthly tuition } \\
\text { cost }\end{array}$} & $1000-2000$ & 26 & 29.9 \\
\hline & $2000-3000$ & 33 & 37.9 \\
\hline & $3000-4000$ & 16 & 18.4 \\
\hline & $4000-5000$ & 22 & 13.8 \\
\hline \multirow{2}{*}{$\begin{array}{l}\text { Parents are good } \\
\text { friend }\end{array}$} & Yes & 63 & 72.4 \\
\hline & No & 24 & 27.6 \\
\hline \multirow{3}{*}{$\begin{array}{c}\text { Takes care about } \\
\text { nutrition }\end{array}$} & Mother & 69 & 79.3 \\
\hline & Both mother \& father & 17 & 19.5 \\
\hline & None & 1 & 1.1 \\
\hline
\end{tabular}

Table 2 shows the percent distribution of the socio-economic and demographic factors that affects the school performance of the students. $88.5 \%$ of the respondents were Muslim and $11.5 \%$ were Hindu. For $85.1 \%$ of the mothers the highest education was either SSC or below SSC. Only $2.3 \%$ of the fathers pursue master degree. $87.4 \%$ of the mothers were housewife. Remaining $8 \%$ engaged with government job and $4.6 \%$ with private job. $74.7 \%$ students lived in a building house and another $25.3 \%$ lived in a building with roof of tin. Monthly tuition cost of the students was divided into four categories, among the groups 2000-3000 TK group retained highest percentage (37.9\%). $72.4 \%$ students thought that their parents are good friend. For $79.3 \%$ cases mothers take care about nutrition. 


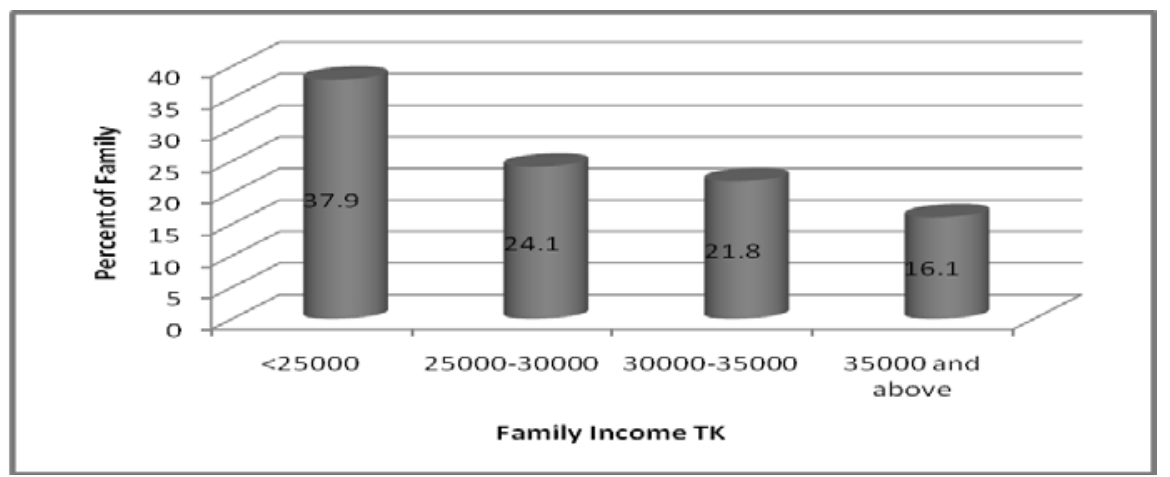

FIG. 1: Category of family income with percent distribution

Figure 1 shows the category of family income with percent distribution. Most of the families (37.9\%) income was below 25000 TK. 24.1\% families had monthly 2500030000 TK. Monthly 30000-35000 TK was earned by 21.8\% families. Only $16.1 \%$ family's monthly income was above $35000 \mathrm{TK}$.

\section{Bivariate analysis:}

Table 3: Cross table with Chi-square test.

\begin{tabular}{|c|c|c|}
\hline Dependent variable & Independent variable & P-value \\
\hline \multirow{4}{*}{$\begin{array}{c}\text { Grade achieved in class } \\
\text { 9 final exam }\end{array}$} & Highest education of mother & 0.048 \\
\cline { 2 - 3 } & Highest education of father & 0.015 \\
\cline { 2 - 3 } & Occupation of father & 0.036 \\
\cline { 2 - 3 } & Occupation of mother & 0.031 \\
\cline { 2 - 3 } & Category of rooms in the house & 0.000 \\
\cline { 2 - 3 } & Trouped earning person in the family & 0.000 \\
\cline { 2 - 3 } & Grouped family income & 0.000 \\
\cline { 2 - 3 } & Monthly tuition cost grouped & 0.000 \\
\cline { 2 - 3 } & Parents are good friend & 0.000 \\
\cline { 2 - 3 } & Takes care about nutrition & 0.000 \\
\hline
\end{tabular}

Table 3 shows that the school performance measured by grade of the students was significantly related with the highest education of mother, highest education of father, occupation of father, occupation of mother, category of rooms in the house, type of house, grouped earning person in the family, grouped family income, monthly tuition cost grouped, parents are good friend, takes care about nutrition because the Chi-square test shows the P-value $<0.01$ (for highest education of mother, highest education of father, occupation of father, occupation of mother, takes care about nutrition $\mathrm{p}<0.05$ ). This indicates that their performances are not same due the different categories of the mentioned socio-economic and demographic variables. 
Rahman and Islam : Nutritional Status and Food Security

Table 4: Correlation between socio-economic and demographic factors and school performance.

\begin{tabular}{|c|c|c|c|}
\hline $\begin{array}{c}\text { Dependent } \\
\text { variable }\end{array}$ & Independent variable & $\begin{array}{c}\text { Correlation } \\
\text { coefficient }\end{array}$ & P-value \\
\hline \multirow{3}{*}{ Class Roll No } & $\begin{array}{c}\text { Actual income of the } \\
\text { family }\end{array}$ & -0.826 & 0.000 \\
\cline { 2 - 4 } & Actual monthly tuition cost & -0.689 & 0.000 \\
\cline { 2 - 4 } & No of rooms in the house & -0.535 & 0.000 \\
\cline { 2 - 4 } & No of earning person & -0.538 & 0.000 \\
\hline
\end{tabular}

Table 4 shows that the school performance measured by class roll number of the students is significantly related with the income of the family, monthly tuition cost, number of rooms in the house, number of earning person because the Chi-square test shows the $\mathrm{P}$-value $<0.01$. 
Multivariate analysis:

Table 5: Comparison of linear models to study the effect of factors on school performance (Class Roll No).

\begin{tabular}{|c|c|c|c|c|c|}
\hline Model & Variable(s) & p-value & B & R Square & $\begin{array}{l}\text { Adjusted } \\
\text { R Square }\end{array}$ \\
\hline $\begin{array}{c}\text { Model-1 } \\
\text { Constant } \\
(0.000)\end{array}$ & $\begin{array}{l}\text { Actual income of } \\
\text { the family }\end{array}$ & 0.000 & -0.002 & 0.683 & 0.679 \\
\hline \multirow{3}{*}{$\begin{array}{c}\text { Model-2 } \\
\text { Constant } \\
(0.000)\end{array}$} & $\begin{array}{l}\text { Actual income of } \\
\text { the family }\end{array}$ & 0.000 & -0.003 & \multirow{3}{*}{0.700} & \multirow{3}{*}{0.689} \\
\hline & $\begin{array}{l}\text { Actual monthly } \\
\text { tuition cost }\end{array}$ & 0.040 & 0.006 & & \\
\hline & $\begin{array}{c}\text { No of earning } \\
\text { person }\end{array}$ & 0.504 & -2.062 & & \\
\hline \multirow{14}{*}{$\begin{array}{c}\text { Model-3 } \\
\text { Constant } \\
(0.001)\end{array}$} & $\begin{array}{l}\text { Actual income of } \\
\text { the family }\end{array}$ & 0.000 & -0.005 & \multirow{14}{*}{0.807} & \multirow{14}{*}{0.769} \\
\hline & $\begin{array}{l}\text { Actual monthly } \\
\text { tuition cost }\end{array}$ & 0.002 & 0.016 & & \\
\hline & $\begin{array}{c}\text { No of earning } \\
\text { person }\end{array}$ & 0.008 & -12.400 & & \\
\hline & $\begin{array}{l}\text { Highest education } \\
\text { of mother }\end{array}$ & 0.182 & 5.278 & & \\
\hline & $\begin{array}{l}\text { Highest education } \\
\text { of father }\end{array}$ & 0.643 & 1.125 & & \\
\hline & $\begin{array}{c}\text { Occupation of } \\
\text { father }\end{array}$ & 0.058 & -2.477 & & \\
\hline & $\begin{array}{l}\text { Occupation of } \\
\text { mother }\end{array}$ & 0.041 & -5.904 & & \\
\hline & $\begin{array}{l}\text { Category of rooms } \\
\text { in the house }\end{array}$ & 0.831 & 0.391 & & \\
\hline & Type of house & 0.076 & 10.386 & & \\
\hline & $\begin{array}{c}\text { Grouped earning } \\
\text { person in the family }\end{array}$ & 0.001 & 22.968 & & \\
\hline & $\begin{array}{c}\text { Grouped family } \\
\text { income }\end{array}$ & 0.001 & 11.090 & & \\
\hline & $\begin{array}{l}\text { Monthly tuition } \\
\text { cost grouped }\end{array}$ & 0.018 & -10.503 & & \\
\hline & $\begin{array}{l}\text { Parents are good } \\
\text { friend }\end{array}$ & 0.011 & 7.418 & & \\
\hline & $\begin{array}{c}\text { Takes care about } \\
\text { nutrition }\end{array}$ & 0.069 & 4.662 & & \\
\hline
\end{tabular}


Model-1 studies only the effects of actual income of the family on school performance. Here all other factors assumed to be constant. Then actual income of the family was found to be significant for class roll no. For model- 1 the value of Rsquare and adjusted R-square were 0.683 and 0.679 respectively.

Model-2 studies the combined effect of actual income of the family, actual monthly tuition cost and number of earning person on school performance. Here two factors (actual income of the family ( $\mathrm{p}=0.000)$, actual monthly tuition cost $(\mathrm{p}=0.040)$ ) were found to be significant. For model-2 the value of R-square and adjusted R-square were 0.700 and 0.689 respectively.

Model-3 studies the aggregate effects of fourteen factors. When we consider all of these factors simultaneously then actual income of the family, actual monthly tuition cost, number of earning person, grouped earning person in the family, grouped family income, monthly tuition cost grouped, parents are good friend were found to be significant at $1 \%$ level of significance and occupation of father, type of house, takes care about nutrition were found to be significant at $10 \%$ level of significance and occupation of mother at $5 \%$ level of significance. For model-3 the value of R-square and adjusted R-square were 0.807 and 0.769 respectively.

\subsection{Effects of Internet Exposure on School Performance}

\section{Descriptive statistics:}

Table 6: Descriptive statistics of internet exposure factors of school performance $(n=87)$.

\begin{tabular}{|c|c|c|c|c|}
\hline Variable & (Mean \pm S.E.) & S.D. & Minimum (hrs) & $\begin{array}{c}\text { Maximum } \\
\text { (hrs) }\end{array}$ \\
\hline $\begin{array}{c}\text { Actual time } \\
\text { spent on internet }\end{array}$ & $1.12 \pm 0.09$ & 0.81 & 0.00 & 3.50 \\
\hline
\end{tabular}

Table 6 depicts the mean, standard deviation, minimum and maximum value for internet exposure factor (actual time spent on internet) that affects school performance. The mean of actual time spent on internet was 1.12 hours. For actual time spent on internet the minimum value was 0.00 hour and the highest value was 3.50 hours. 
Frequency distribution:

Table 7: Frequency distribution of internet exposure factors of school performance $(n=87)$.

\begin{tabular}{|c|c|c|c|}
\hline Variable & Category & Frequency & Percent (\%) \\
\hline \multirow{3}{*}{ Internet use } & Yes & 70 & 80.5 \\
\cline { 2 - 4 } & No & 17 & 19.5 \\
\hline \multirow{3}{*}{ Work on internet } & Don’t use & 17 & 19.5 \\
\cline { 2 - 4 } & $\begin{array}{c}\text { Educational } \\
\text { materials }\end{array}$ & 18 & 20.7 \\
\cline { 2 - 4 } & Read newspaper & 5 & 5.7 \\
\cline { 2 - 4 } & Browse & 3 & 3.4 \\
\cline { 2 - 4 } & Entertainment & 44 & 50.6 \\
\hline \multirow{2}{*}{$\begin{array}{c}\text { Facebook } \\
\text { account }\end{array}$} & Yes & 69 & 79.3 \\
\cline { 2 - 4 } & No & 18 & 20.7 \\
\hline
\end{tabular}

Table 7 shows the percent distribution of the internet exposure factors that affects the school performance. $80.5 \%$ of the students were exposed to internet. $20.7 \%$ students used internet for educational purposes. Majority of the students (50.6\%) used internet for entertainment. Among the internet users $79.3 \%$ have Facebook account.

FIG. 2: Percent distribution of daily time spent on internet.

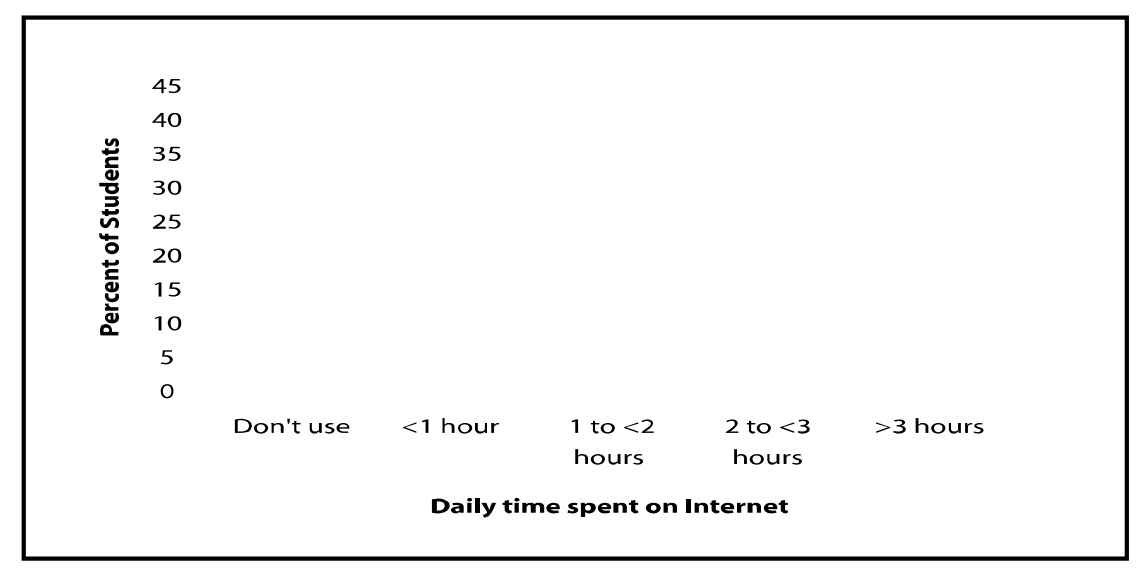

Figure 2 shows the percent distribution of daily time spent on internet. Here $13.8 \%$ students spent less than one hour per day. 41.4\% students spent 1 hour to less than 2 hours, $24.1 \%$ students spent 2 hour to less than 3 hours. Only 1.1\% students spent more than 3 hours. 19.5\% students did not have internet accessibility. 
FIG. 3: Percent distribution of number of friends in Facebook.

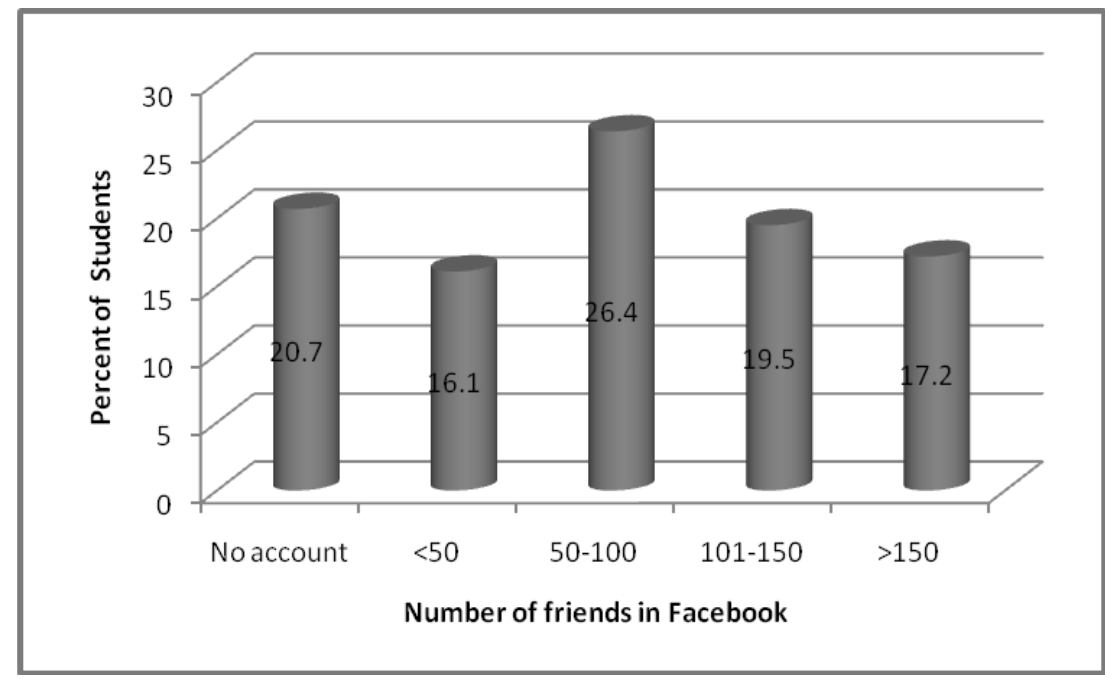

Figure 3 shows the percent distribution of number of friends in Facebook. 20.7\% students did not have Facebook account. 16.1\% students had less than 50 friends. 50-100 and 101-150 category possessed 26.4\% and 19.5\% Facebook users. 17.2\% students had more than 150 friends.

\section{Bivariate analysis:}

Table 8: Cross table with Chi-square test.

\begin{tabular}{|c|c|c|}
\hline Dependent variable & Independent variable & P-value \\
\hline $\begin{array}{c}\text { Grade achieved in class } \\
9 \text { final exam }\end{array}$ & Work on internet & 0.000 \\
\cline { 2 - 3 } & No of friends in Facebook & 0.000 \\
\hline
\end{tabular}

Table 8 shows that the school performance measured by grade of the students was significantly related with the work on internet, number of friends in Facebook because the Chi-square test shows the $\mathrm{P}$-value $<0.01$. This indicates that their performances are not same due to the different categories of the mentioned internet exposure related variables. 
Multivariate analysis:

Table 9: Comparison of linear models to study the effect of factors on school performance (Class Roll No).

\begin{tabular}{|c|c|c|c|c|c|}
\hline Model & Variable(s) & p-value & B & R Square & $\begin{array}{l}\text { Adjusted } \\
\text { R Square }\end{array}$ \\
\hline $\begin{array}{c}\text { Model-1 } \\
\text { Constant } \\
(0.000)\end{array}$ & Work on internet & 0.000 & 4.635 & 0.158 & 0.148 \\
\hline \multirow[b]{2}{*}{$\begin{array}{c}\text { Model-2 } \\
\text { Constant } \\
(0.000)\end{array}$} & Work on internet & 0.649 & 0.999 & \multirow[b]{2}{*}{0.195} & \multirow[b]{2}{*}{0.176} \\
\hline & $\begin{array}{l}\text { No of friends in } \\
\text { Facebook }\end{array}$ & 0.055 & 5.254 & & \\
\hline \multirow{6}{*}{$\begin{array}{c}\text { Model-3 } \\
\text { Constant } \\
(0.008)\end{array}$} & Internet use & 0.117 & 29.221 & \multirow{6}{*}{0.435} & \multirow{6}{*}{0.392} \\
\hline & $\begin{array}{l}\text { Actual time spent } \\
\text { on internet }\end{array}$ & 0.465 & -6.093 & & \\
\hline & $\begin{array}{l}\text { Daily time spent } \\
\text { on internet }\end{array}$ & 0.711 & 2.774 & & \\
\hline & Work on internet & 0.052 & 4.001 & & \\
\hline & Facebook account & 0.072 & 5.931 & & \\
\hline & $\begin{array}{l}\text { No of friends in } \\
\text { Facebook }\end{array}$ & 0.000 & 10.329 & & \\
\hline
\end{tabular}

Model-1 studies only the effects of work on internet on school performance. Here all other factors assumed to be constant. Then works on internet was found to be significant for class roll no. For model-1 the value of R-square and adjusted Rsquare were 0.158 and 0.148 respectively.

Model-2 studies the combined effects of works on internet and number of friends in Facebook on school performance. Number of friends in Facebook was found to be significant. For model-2 the value of R-square and adjusted R-square were 0.195 and 0.176 respectively.

Model-3 studies the aggregate effects of six factors. When we consider all of these factors simultaneously then number of friends in Facebook was found to be significant at $1 \%$ level of significance, and work on internet and Facebook account at $10 \%$ level of significance. For model-3 the value of R-square and adjusted Rsquare were 0.435 and 0.392 respectively.

\section{Discussion:}

\subsection{Effects of Socio-Economic \& Demographic Factors on School Performance:}

Class roll number were highly negatively correlated with the factors-actual income of the family, actual monthly tuition cost, number of rooms in the house, number of earning persons in the family, and this correlation was significant $(p<0.01)$ at $1 \%$ level of significance (Table 4). We have made a cross check by using Chi-square 
test for association between the category of these factors and the school performance measured by grade. Chi-square test also found highly significant (Table 3). In Chi-square test some of the other factors namely highest education of mothers $(p<0.05)$, highest education of fathers $(p<0.05)$, occupation of fathers $(\mathrm{p}<0.01)$, and occupation of mothers $(\mathrm{p}<0.05)$ were significant.

The associations (between school performance and socio-economic and demographic factors) that were found in this study are strongly supported by the following previous studies:

- Family background is key to a students' life and outside of school, is the most important influence on student learning ${ }^{4}$.

- Studies have repeatedly found that socio-economic status (SES) affects student outcomes $5,2,3,4,7,8,9$.

- Students who have a low SES earn lower test scores and are more likely to drop out of school ${ }^{3,7}$.

- Research shows that supportive and attentive parenting practices positively affect academic achievement ${ }^{3}$.

- Maternal characteristics are another key factor that affect academic achievement ${ }^{5,3,4}$.

Finally from the model- 1 of table 5 we found that as actual income of the family increases by 1 unit class roll no decreased (improvement of school performance) by less than 1 unit at 1\% level of significance. Here actual income of the family was responsible for $68.3 \%$ change in school performance. Maximum $80.7 \%$ change was found from the model-3. In this model we studied the aggregate effects of fourteen factors. When we consider all of these factors simultaneously then actual income of the family, actual monthly tuition cost, number of earning person, grouped earning person in the family, grouped family income, monthly tuition cost grouped, parents are good friend were found to be significant at $1 \%$ level of significance and occupation of father, type of house, takes care about nutrition were found to be significant at $10 \%$ level of significance and occupation of mother at $5 \%$ level of significance.

\subsection{Effects of Internet Exposure on School Performance:}

The school performance measured by grade of the students was significantly related with the work on internet, number of friends in Facebook because the Chi-square test shows the $\mathrm{P}$-value $<0.01$ (Table 8 ).

The associations (between school performance and internet exposure factors) that were found in this study are strongly supported by the following previous studies:

- In an unpublished Master's thesis ${ }^{10}$ found that heavy Facebook use (i.e., more time spent on Facebook) is observed among students with lower GPAs. 
- More recently an exploratory survey study reported a negative relationship between Facebook use and academic achievement as measured by self reported GPA and hours spent studying per week ${ }^{11}$.

Finally in model-1 of table 9 work on internet was highly significant $(\mathrm{p}=0.00)$ and this factor had an effect on school performance by $15.8 \%$ change. Model-2 exerted $19.5 \%$ changes when two factors (work on internet and no of friends in Facebook) included. Maximum $43.5 \%$ changes occurred in model-3, where number of friends in Facebook was significant at $1 \%$ level of significance and both work on internet and Facebook account were significant at $10 \%$ level of significance.

\section{References:}

1. sBattle, Juan. and Michael Lewis. 2002. The increasing significance of class: The relative effects of race and socioeconomic status on academic achievement. Journal of Poverty, 6(2), 21-35.

2. Jeynes, William H. 2002. Examining the effects of parental absence on the academic achievement of adolescents: the challenge of controlling for family income. Journal of Family and Economic Issues 23(2).

3. Eamon, Mary. Keegan. 2005. Social-demographic, school, neighborhood, and parenting influences on academic achievement of Latino young adolescents. Journal of Youth and Adolescenc, 34(2), 163-175.

4. Majoribanks, Kevin. 1996. Family Learning Environments ans Students' Outcomes: Review. Journal of Comparitive Family Studies 27(2), 373-394.

5. Baharudin, Rozumah and Tom Luster. 1998. Factors related to the quality of the home environment and children's achievement. Journal of Family Issues. 19(4), 375-403.

6. Espionosa, I. M. , Laffey, J.M. , Whitteker, T. , \& Sheng, Y. (2006). Technology in the home and the achievement of young children: Finding from the Early Childhood Longitudinal Study. Early Education and Development, 17, 421-441.

7. Hochschild, Jennifer L. 2003. Social Class in Public Schools. Journal of Social Issues 59(4), 821-840.

8. McNeal, Ralph B. 2001. Differential effects of parental involvement on cognitive and behavioral outcomes by socioeconomic status. Journal of Socio-Economics 30(2), 171.

9. Seyfried, Sherri.F. 1998. Academic achievement of African American preadolescents: The influence of teacher perceptions. American Journal of Community Psychology, 26(3), 381-402.

10. Boogart, V. and Robert, M. 2006. Uncovering the social impacts of Facebook on a college campus, Kansas State University.

11. Karpinski, A. C. , \& Duberstain, A. A description of Facebook use and academic performance among undergraduate and graduate students. In poster presented at the meeting of the American Educational Research Association on April 16, San siego, CA, 2009. 